\title{
Commentary
}

\section{Is R2P a Fully-Fledged International Norm?}

\author{
Jason Ralph ${ }^{1,2, *}$ and James Souter ${ }^{1}$ \\ ${ }^{1}$ POLIS, University of Leeds, Leeds LS2 9JT, UK; E-Mails: j.g.ralph@leeds.ac.uk (J.R.), j.souter@leeds.ac.uk (J.S.) \\ ${ }^{2}$ POLSIS, University of Queensland, St Lucia, QLD 4072, Australia \\ * Corresponding author
}

Submitted: 11 May 2015 | Accepted: 13 May 2015 | Published: 26 November 2015

\begin{abstract}
This commentary examines whether R2P is a fully-fledged norm. As a normative aspiration R2P is almost universally accepted. However as a standard of behaviour that states implement as a matter of course R2P is far from fully-fledged. By examining state responses to refugee crises in Syria it is argued that powerful states are failing in their special responsibility to protect.
\end{abstract}

\section{Keywords}

asylum; atrocity; R2P; special responsibility to protect; Syria

\section{Issue}

This commentary is part of the special issue "Mass Atrocity Prevention", edited by Professor Karen E. Smith (London School of Economics and Political Science, UK).

(C) 2015 by the authors; licensee Cogitatio (Lisbon, Portugal). This article is licensed under a Creative Commons Attribution 4.0 International License (CC BY).

What would it mean to say R2P is a fully-fledged international norm? There are several aspects to answering this question. The first is to understand what we are talking about when we use the term "norm". This word is used to describe both an existing social reality and an aspiration for a new reality. That can be the cause of some confusion. As an aspiration R2P is clear. It articulates a universal standard of appropriate behaviour. States should protect their populations and when they manifestly fail to do that the international community should protect those populations. Because this is clear, and because it was unanimously adopted by states in 2005, we might say the R2P is fully-fledged as a normative aspiration. As Alex Bellamy (2015, p. 12) notes, "the key debates now are ones about how best to implement R2P, not about whether to accept the principle itself". The question becomes more complex, however, when we use "norm" to describe social reality. From this perspective we can say that R2P is a norm because states are more conscious of their responsibilities to protect populations (their own and others) and because they are aware that if they fail to protect their own populations other states (or entities like the ICC) might intervene in their internal affairs. Bellamy (Bellamy 2015, p. 8) offers strong evidence that this too is clearly the case. The number of United Nations Security Council resolutions reminding states and UN peace operations of their responsibility to protect has increased. States-if not their populations-are more aware of their responsibility to protect. But it seems any description of R2P as a norm (especially a fullyfledged norm) demands more. If we use that term to describe social reality rather than normative aspiration then we are surely using it to describe the fulfilment of the responsibility R2P articulates and states accept.

This poses a more demanding set of criteria and opens up a further set of questions. What does it mean to fulfil the responsibility states recognise and do all states have the same responsibilities? On the first, it is far too simplistic to say the continuing commission of atrocities demonstrates the failure of R2P to influence reality. This ignores the fact that states for the most part do not commit atrocity crimes, a standard thatwe accept-predates 2005. But more significantly, citing the evidence of ongoing atrocities as evidence of R2P's failure ignores instances where states have acted 
collectively to protect populations from such crimes. Evidence that international intervention has actually prevented violence and protected populations is available (UN News Centre 2015). R2P is not simply a matter of declaring the intention to protect in an increased number of UN Resolutions. Moreover, we cannot expect R2P to dictate state behaviour because, of course, states do have other responsibilities. These include responsibilities to their own citizens, as well as a responsibility to deliberate with other states as part of a process that is necessary to determine how best to protect. Now obviously there is a risk here that an emphasis on deliberation can be spun in a negative way. We are fully aware that the images of unhurried diplomacy do not look good against the images of immediate suffering. The "do something" mantra is always right. But so is the "do what?" question; and in some instances, such as Syria, it is not always obvious about what should be done, which means there is a responsibility to deliberate. As Jennifer Welsh (Welsh, 2013) writes, R2P involves "the responsibility to consider" what can be done to protect.

Deliberation in this sense is necessary to find appropriate solutions to existing problems, but it can also reveal the tragic nature of the problem, which-in its strictest sense-involves making a choice from scenarios that are equally bad (Brown, 2007). But tragedy is not a permanent feature of human relations (Erskine \& Lebow, 2012). Deeply embedded in the R2P norm is a responsibility to "reduce our vulnerability to tragedy" - the phrase is Richard Ned Lebow's (2012, p. 65)and that requires broader conceptualisations of the norm. Take the crisis in Syria as an example. Because the focus has been on events inside Syria there is a tendency to say either that R2P has failed to influence events or that protection is not a prudent option. Obviously the Syrian government has "manifestly failed" to protect its population. But has the international community manifestly failed? At the most demanding level, the answer again is yes. It did not come to a consensus in a way that stopped the killing inside Syria. But at another level it did accept the responsibility to consider what ought to be done and some access for humanitarian relief operations has been negotiated. But let us look at what has been happening outside Syria. From this perspective we get a very different view of R2P. It leads us to consider what more could have been done and it leads us to the second question about whether all states have the same responsibility to protect.

The atrocities inside Syria have caused a refugee crisis outside that state. Aside from dead bodies, refugees are perhaps the most obvious manifestation of atrocity crimes. People protect themselves by fleeing persecution and violence. Because R2P tells us the international community has a responsibility to assist these people and to protect them it surely implies guaranteeing a form of asylum. Again, this predates
R2P. The 1951 Refugee Convention has long since articulated a responsibility to those with a "well-founded fear of persecution". But if the R2P norm is about creating the political will so that states fulfil their responsibilities as a matter of course, then R2P (both the scholarly articulation of it and state practice) is not fully-fledged. Few authors talk about asylum as a tool of R2P. Those that do suggest "[ $t$ ]here may be no easier way for the international community to meet its responsibility to protect than by providing asylum and other international protection on adequate terms" (Barbour \& Gorlick, 2008, p. 533; see also Davies \& Glanville, 2010; Orchard, 2014). The relative lack of attention, moreover, distorts our assessment of state responses to Syria. The responsibility to protect is being fulfilled in those states-Turkey, Lebanon, Jordan, Egypt and Iraq-that have taken in nearly four million refugees between them. R2P's influence is not simply confined to chambers and corridors of the UN in New York. Victims of atrocity crimes are being protected. As far as Syria is concerned, R2P is not entirely failing but the world is relying on five states to uphold it.

This begs the question of what others are doing to assist these states. This is particularly pertinent for those states which claim to promote R2P and for those that have a "special responsibility to protect". The idea of a "special responsibility to protect" is a way of allocating the burden of meeting what would otherwise be an unspecified and general responsibility. This is necessary because there is a risk that R2P-as a general (and somewhat unspecified) norm-will not be fulfilled if states expect others (such as those in the region) to bear the burden. A special responsibility is often thought of as "significantly more strenuous" (Kagan, 1988) than a general responsibility and Mlada Bukovansky et al. (2012) have recently argued that such responsibilities can be allocated based on a capacity to do good. If we take this to be the case then surely the strongest states are failing in their responsibility to protect. As noted, this is not a question of humanitarian military intervention. Military strength is redundant when a military solution is not available. Strength here is the capacity to protect the vulnerable by providing a form of asylum and it is obvious in the case of Syria that the strongest are not meeting their responsibility. Among European states, for instance, only Germany can claim to be meeting its responsibility when considering the number of resettlement pledges per capita alongside GDP per capita. States like the UK, Denmark and the Netherlands "all stand out as being countries which could afford to shelter more refugees of the Syrian conflict" (Gracio, 2015).

Bukovansky et al. (2012, p. 220) also argued that those bearing a special responsibility "should not be entitled to successful appeal to undue costs in those situations where they deliberately, recklessly or negligently created the situation of vulnerability". It is hard 
to argue that outside states were culpable of creating the Syrian population's situation of vulnerability. This stands in contrast to the role of outside states such as the UK and Australia in creating the vulnerability of Iraq to Islamic State (Ralph \& Souter, 2015). Of course, there was a greater level of previous external intervention there than there was in Syria. One might argue that certain external states bear a special responsibility by virtue of their omissions - e.g. a failure to overthrow Assad-but this is weak given the significant uncertainty that such actions would have eased the population's vulnerability. Many states, not least the Chinese, argued that regime change leads to political instability, which in turn leads to more, if not greater, vulnerability and harm. Their preference was for a political solution that included the Assad regime. Those making this argument can now, moreover, cite external interventions such as Libya in 2011 to make their point. External humanitarian intervention may have been necessary in 2011-a point the Chinese acknowledged with their abstention on Resolution 1973-but regime change (either as a goal or as a consequence of the intervention) always risked creating a power vacuum, which in turn would create a new situation of vulnerability. By 2015 this concern seemed to be realised in the events in Libya.

It might be hard to connect European actions to the cause of the humanitarian crisis inside Syria, but its link to the fate of refugees that have fled the violence is less difficult to establish. Indeed commentators have noted how European actions have exacerbated the vulnerability of refugees in a number of ways. For instance, a new fence between Greece and Turkey "stopped migration across the land border, but led to a doubling in-more dangerous-crossings of the Aegean in the first half of 2014" (Anonymous, 2015). In addition the EU cut the resources it devoted to search and rescue missions under the misplaced assumption that such missions were acting as a "pull" factor for migrants and the boat trips would stop if the missions were withdrawn (Anonymous, 2015; see also Davies \& Orchard, 2015). It is also possible to argue that the NATO-led intervention in Libya, or at least the failure to leave a functioning government in place, has contributed to the situation of vulnerability. Not only has the civil war there displaced more than 400,000 Libyans, the lack of authority there has hindered a humanitarian response to those fleeing other conflicts as they to try to cross into Europe. The charge that Europe failed in its responsibility to rebuild Libya became something of a political football in the 2015 British election, but that does not mean there was no substance to it (Paterson, 2015). Alexander Betts makes a similar point, suggesting that external powers that destabilize countries through their foreign policies have a moral responsibility to do more. This means going beyond providing asylum - which can mean only protecting those who arrive on one's territory-and acting on a responsibility to assist other states by sharing the responsibility for refugee protection through resettlement schemes (Betts, 2015).

All this suggests the R2P norm is far from fullyfledged if by that we take it to mean states fulfil their responsibilities as a matter of course. But here we agree with Bellamy, R2P has immense potential. States accept it as a normative aspiration. If we are to deliver on that potential, however, we have to take a critical perspective, particularly on the record of those states that have a special responsibility to do more because they have a unique capacity, and especially when they are culpable of creating or exacerbating situations of vulnerability. That does not mean, as we have argued, strengthening further the powerful state's commitment to military intervention. Military intervention poses many risks to the national interest and to the populations the responsible state is trying to protect. We witnessed in 2014 and 2015 the consequences of military intervention in Libya. It was not necessarily inevitable that the 2011 intervention would lead to the collapse of that state, but if military intervention inevitably leads to regime change-which the P3 argued was the case-then the risk of state collapse was always going to be high. Again this does not mean that R2P should evolve in a way that excludes the kind of military intervention that only the powerful states can provide. But it does mean that military intervention is not the only way strong states can meet their special responsibility to protect. These states should, as Jennifer Welsh (2014) has argued, stop looking at R2P as if it is something that is done by functioning states outside their territory and inside the territory of failing states. The responsibility to protect is sometimes best dealt with inside functioning states. This requires a shift in the discourse on R2P so that it asylum is not forgotten as a means of assessing whether the capable and culpable are fulfilling their special responsibility to protect.

\section{Acknowledgments}

Funding for this research was made available by the European Union Framework 7 Marie Curie Actions, and Research Councils UK's "Rights and Ethics in a Security Context" Programme (grant number ES/L013355/1).

\section{Conflict of Interests}

The authors declare no conflict of interests.

\section{References}

Anonymous. (2015, April 25). Europe's boat people. The EU's policy on maritime refugees has gone disastrously wrong. The Economist. Retrieved from 
http://www.economist.com/news/leaders/2164946 5-eus-policy-maritime-refugees-has-gone-disastrou sly-wrong-europes-boat-people/comments?page=1

Barbour, B., \& Brian G. (2008). Embracing the "responsibility to protect": A repertoire of measures including asylum for potential victims. International Journal of Refugee Law, 20(4), 533-566.

Bellamy, A. (2015). The responsibility to protect: A defense ( $1^{\text {st }}$ ed.). Oxford: Oxford University Press.

Betts, A. (2015, April 26). Forget the "war on smuggling", we need to be helping refugees in need. The Guardian. Retrieved from http://www.theguardian. com/commentisfree/2015/apr/25/war-ontrafficking-wrong-way-to-tackle-crisis-of-migrantdeaths?CMP=share_btn_tw

Brown, C. (2007). Tragedy, "tragic choices" and contemporary international political theory. International Relations, 21(1), 5-13.

Bukovansky, M., Clark, I., Price, R., Reus-Smit, C., \& Wheeler, N. (2012). Special responsibilities. Global problems and American power ( $1^{\text {st }}$ ed.). Cambridge: Cambridge University Press.

Davies, S. E., \& Glanville, L. (2010). Protecting the displaced: Deepening the responsibility to protect. Vol. 1. Boston; Leiden: Martinus Nijhoff Publishers.

Davies, S. E., \& Orchard, P. (2015, April 23). Would Australia's asylum seeker policy stop boats to Europe? The Conversation. Retrieved from http://theconversation.com/would-australiasasylum-seeker-policy-stop-boats-to-europe-40645

Erskine, T., \& Lebow, R. N. (2012). Understanding tragedy and understanding international relations. In T. Erskine \& R. N. Lebow (Eds.), Tragedy and international relations (pp. 1-18). New York, NY: Palgrave Macmillan.
Gracio, F. (2015, March 13). Hard evidence: How much are European countries doing to help shelter Syrian refugees? The Conversation. Retrieved from http://theconversation.com/hard-evidence-howmuch-are-european-countries-doing-to-helpshelter-syrian-refugees-38731

Kagan, S. (1988). Causation and responsibility. American Philosophical Quarterly, 25(4), 293-302.

Lebow, R. N. (2012). Tragedy, politics and political science. In R. N. Lebow \& T. Erskine (Eds.), Tragedy and international relations (pp. 63-71). New York, NY: Palgrave Macmillan.

Orchard, P. (2014). A right to flee: Refugees, states, and the construction of international cooperation $\left(1^{\text {st }}\right.$ ed.). New York, NY; Cambridge: Cambridge University Press.

Paterson, J. (2015, April 21). Is Libyan migrant crisis the UK's fault? BBC News. Retrieved from http://www. bbc.com/news/election-2015-32381621

Ralph, J. G., \& Souter, J. (2015). A special responsibility to protect: The UK, Australia and the rise of Islamic State. International Affairs, 91(4), 709-723.

UN News Centre. (2015, February 17). In South Sudan, protection of civilians "critical part" of UN mandate. Retrieved from http://www.un.org/apps/news/ story.asp?NewsID=50103\#.VeBAWI1wb5o

Welsh, J. (2014). Fortress Europe and the responsibility to protect: Framing the issue. The "Lampedusa dilemma": Global flows and closed borders. What should Europe do? Retrieved from http://www. eui.eu/Documents/RSCAS/PapersLampedusa/FORU M-Welshfinal.pdf

Welsh, J. (2013). Norm contestation and the responsibility to protect. Global Responsibility to Protect, 5(4), 365-396.

\section{About the Authors}

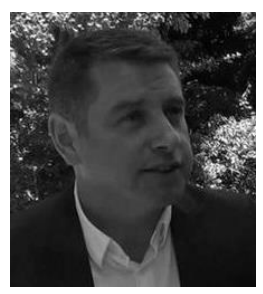

Professor Jason Ralph

Jason Ralph is a Professor of International Relations at the School of Politics and International Studies, University of Leeds and Honorary Professor at the University of Queensland. He is currently a Marie Curie International Outgoing Fellow, which included a visiting researcher position at the AsiaPacific Centre for the Responsibility to Protect.

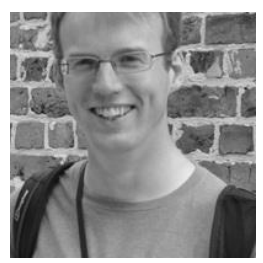

\section{Dr. James Souter}

James Souter is a RCUK Post-Doctoral Research Fellow at the School of Politics and International Studies, University of Leeds. He completed a DPhil entitled "Asylum as Reparation" at the Refugee Studies Centre, University of Oxford, in 2014. 